\title{
Profil Penguasaan Konsep Ikatan Kimia pada Siswa Kelas X SMA Negeri 4 Palangka Raya Tahun Ajaran 2017/2018
}

\author{
Abdul Malik Sampurna*, Mulawi, I Made Sadiana \\ Program Studi Pendidikan Kimia, Jurusan Pendidikan MIPA, FKIP, Universitas \\ Palangka Raya, Indonesia \\ E-mail: sampurna25091996@gmail.com
}

Diterima: 30 Januari 2020; Disetujui: 14 Februari 2020; Diterbitkan: 03 Maret 2020

\begin{abstract}
ABSTRAK
Konsep ikatan kimia merupakan salah satu materi pelajaran kimia SMA kelas X. Penelitian ini bertujuan untuk mendeskripsikan penguasaan konsep ikatan kimia pada siswa kelas X SMA Negeri 4 Palangka Raya Tahun Ajaran 2017/2018. Penelitian ini termasuk jenis penelitian kualitatif yang bersifat deskriptif. Subjek penelitian ini adalah 29 siswa kelas X SMA Negeri 4 Palangka Raya Tahun Ajaran 2017/2018 yang sudah menerima pembelajaran materi ikatan kimia. Data yang digunakan pada penelitian ini berupa dokumen RPP yang didapat dari guru yang bersangkutan. Data penguasaan konsep siswa diperoleh melalui tes uraian ikatan kimia menggunakan 7 butir soal esai yang mencakup 5 indikator. Data pendukung menggunakan hasil wawancara terhadap siswa. Penguasaan konsep siswa dalam menuliskan konfigurasi elektron dan menentukan elektron valensi unsur 94\% dengan kategori sangat tinggi. Penguasaan konsep menggambarkan struktur Lewis 62\% kategori sedang. Penguasaan konsep menggambarkan cara suatu unsur untuk mencapai kestabilan $74 \%$ kategori tinggi. Penguasaan konsep mengelompokan unsur gas mulia dan bukan gas $22 \%$ kategori rendah. Penguasaan konsep menjelaskan aturan duplet dan aturan oktet $20 \%$ kategori rendah. Penguasaan konsep menjelaskan proses terbentuknya ikatan ion $49 \%$ berada pada kategori sedang. Penguasaan konsep menggambarkan struktur Lewis dan menentukan rumus kimia senyawa ikatan kovalen tunggal $51 \%$ kategori sedang. Penguasaan konsep menggambarkan struktur Lewis dan menentukan rumus kimia senyawa ikatan kovalen rangkap dua $65 \%$ berada pada kategori sedang. Penguasaan konsep menggambarkan struktur Lewis dan menentukan rumus kimia senyawa ikatan kovalen rangkap tiga 40\% kategori rendah. Penguasaan konsep menjelaskan proses terbentuknya ikatan kovalen koordinasi 29\% kategori rendah. Penguasaan konsep menjelaskan proses pembentukan ikatan logam dan menjelaskan sifat senyawa yang berikatan logam masing-masing $31 \%$ dan $45 \%$ kategori rendah.
\end{abstract}

Kata Kunci: ikatan kimia, penguasaan konsep, profil

\section{PENDAHULUAN}

Ilmu kimia merupakan bagian dari ilmu pengetahuan alam yang mempelajari tentang sifat, struktur materi, komposisi materi, perubahan, dan energi yang menyertai perubahan energy. Dalam ilmu kimia terdapat dua jenis penguasaan yang harus dikuasai oleh siswa, yaitu penguasaan konseptual dan penguasaan algoritmik. Penguasaan konseptual merupakan penguasaan tentang 
hal-hal yang berhubungan dengan konsep, yaitu arti, sifat, dan uraian suatu konsep dan juga kemampuan dalarn menjelaskan teks, diagram, dan (fenomena yang melibatkan konsep-konsep pokok yang bersifat abstrak dan teori-teori dasar sains). Penguasaan algoritmik merupakan penguasaan tentang prosedur atau serangkaian peraturan yang melibatkan perhitungan matematika untuk memecahkan suatu masalah (Ghalib, 2009).

Ilmu kimia direpresentasikan ke dalam tiga level yaitu level makroskopik, level sub-mikroskopik, dan level simbolik. Level makroskopik berisi hal-hal nyata yang dapat diamati secara fisik, seperti fenomena kimia yang terjadi dalam kehidupan sehari-hari maupun fenomena di laboratorium. Level sub-mikroskopik berisi level partikel yang dapat digunakan untuk menggambarkan bentuk partikulat dari suatu fenomena kimia, misalnya pergerakan elektron, molekul, partikel ,dan atom. Level simbolik adalah representasi berupa gambar, angka, huruf, dan simbol yang mewakili suatu kejadian, misalnya persamaan reaksi kimia dan grafik (Sulistyowati \& Poedjiastoeti, 2013).

Materi ikatan kimia merupakan salah satu pokok bahasan yang dipelajari di SMA/MA yang dimuat dalam level sub-mikroskopik. Pada kurikulum 2013 pokok bahasan ini diajarkan pada kelas X SMA semester genap. Struktur masalah pengetahuan tentang ikatan kimia yang disajikan sangat penting dan perlu merefleksikan tujuan pembelajaran yang dimaksudkan (Asi, 2018).

Penelitian yang dilakukan Yulieet (2015) tentang pemahaman konsep ikatan ion pasca pembelajaran dengan metode diskusi Berbantuan Media Handout bergambar pada siswa kelas X lintas minat SMAN 4 Palangka Raya tahun ajaran 2015/2016 menunjukan bahwa pemahaman konsep siswa pada materi ikatan ion meningkat. Penelitian lain yang dilakukan Asi (2018) dan Otania (2018) menunjukkan terdapat pengaruh penggunaan LKS terhadap pemahaman ikatan ion dan ikatan kovalen.

Hasil penelitian diatas dilakukan dengan memberikan perlakuan kepada siswa berupa LKS. Dapat disimpulkan bahwa pemahaman siswa pada konsep ikatan kimia masih rendah. Berdasarkan pemahaman siswa yang masih rendah maka dikumpulkan informasi dan menganalisis bagaimana penguasaan konsep siswa dari proses pembelajaran disekolah dan tanpa diberikan suatu perlakuan terhadap subjek penelitian, sehingga judul penelitian ini adalah "Profil Penguasaan Konsep Ikatan Kimia pada Siswa Kelas X SMA Negeri 4 Palangka Raya Tahun Ajaran 2017/2018”.

\section{METODOLOGI PENELITIAN}

Penelitian ini di laksanakan di SMA Negri 4 Palangka Raya yang beralamat di jl. Sisinga Mangaraja 3 nomer 3 kelurahan jekan raya. Semua siswa diwajibkan untuk memiliki sumber belajar berupa buku pelajaran.

Subjek penelitian ini adalah siswa kelas X-10 SMA Negri 4 Palangka Raya. Siswa tersebut telah menerima pembelajaran ikatan kimia pada Kelas X-10 semester genap (II). Pengambilan data dokumen RPP dilakukan pada bulan agustus 2018, tes penguasaan konsep ikatan kimia dilakukan di SMA Negeri 4 Palangka raya tanggal 26 November 2018 yang melibatkan 29 siswa kelas X-10 SMA Negeri 4 Palangka Raya yang berperan sebagai subjek penelitian dengan alokasi waktu dua jam pelajaran (90 menit).

Teknik analisis data dalam penelitian ini adalah data tes ikatan kimia 
berupa hasil tes uraian yang dianalisis secara deskriptif dengan langkah-langkah sebagai berikut:

1. Jawaban siswa diberi skor sebagai data untuk mengetahui skor siswa sesuai dengan kriteria penskoran. Soal yang digunakan dalam penelitian ini berbentuk uraian yang berjumlah 7 butir soal. Hasil skor yang diperoleh digunakan untuk mendeskripsikan penguasaan konsep siswa tentang ikatan kimia. Penilaian sesuai dengan deskripsi penguasaan konsep siswa dalam tingkat penguasaan konsep ikatan kimia yang disajikan pada lampiran 3.

2. Total perolehan skor seluruh siswa digunakan untuk menentukan penguasaan konsep siswa secara keseluruhan menggunakan rumus:

$$
\text { Penguasaan konsep siswa }=\frac{\text { Jumlah skor jawaban yang diperoleh }}{\text { Jumlah skor total }} \times 100 \%
$$

3. Penguasaan konsep siswa dikategorisasi sesuai kriteria penguasaan konsep yang disarankan oleh Arikunto.

Tabel 3. Kriteria Penguasaan Konsep (Arikunto, 2007)

\begin{tabular}{cc}
\hline Penguasaan Konsep Siswa (\%) & Kategori \\
\hline $86-100$ & Sangat Tinggi \\
$66-85$ & Tinggi \\
$46-65$ & Sedang \\
$0-45$ & Rendah \\
\hline
\end{tabular}

4. Penguasaan konsep siswa dideskripsikan berdasarkan jawaban siswa pada masing-masing kategori tingkat penguasaan konsep siswa.

5. Penguasaan konsep merupakan rata-rata penguasaan konsep pada materi ikatan kimia yang diukur dari pencapaian indikator, ditentukan dengan rumus:

Penguasaan konsep $=\frac{\sum \text { persentase penguasaan konsep per indikator }}{\sum \text { indikator }}$

\section{HASIL PENELITIAN DAN PEMBAHASAN}

Hasil jawaban siswa kemudian diolah sebagai data penguasaan konsep siswa. Butir soal pada tes uraian mewakili setiap konsep-konsep pada materi tatanama senyawa dan persamaan reaksi, dimana butir soal memiliki kriteria penskoran. Total skor yang didapatkan siswa dikonversikan dalam bentuk persentase penguasaan dan kemudian diklasifikasikan kedalam tingkat penguasaan siswa. Penguasaan konsep siswa pada materi ikatan kimia disajikan pada tabel 4.

Tabel 4 menunjukkan bahwa penguasaan konsep siswa pada materi ikatan kimia berada pada kategori sedang dengan rata-rata persentase penguasaan konsep sebesar 55\%. Penguasaan konsep siswa ditinjau dari lima indikator, dimana penguasaan konsep siswa pada indikator-1 yaitu menjelaskan proses suatu unsur untuk mencapai kestabilannya. Pada indikator-2 menggambarkan susunan elektron valensi atom gas mulia (duplet dan okted) dan elektron valensi bukan gas mulia (struktur Lewis). Indikator-3 menjelaskan proses terbentuknya ikatan ion. Indikator-4 menjelaskan proses terbentuknya ikatan kovalen. Indikator-5 menjelaskan proses terbentuknya ikatan logam dan hubunganya dengan sifat senyawa yang berikatan logam. 
Tabel 4. Penguasaan konsep siswa pada materi ikatan kimia

\begin{tabular}{|c|c|c|c|c|}
\hline Indikator & Sub Indikator & $\begin{array}{l}\text { Nomor } \\
\text { Butir } \\
\text { Soal }\end{array}$ & $\begin{array}{l}\text { Penguasaan } \\
\text { Konsep (\%) }\end{array}$ & Kategori \\
\hline \multirow{4}{*}{$\begin{array}{l}\text { Menjelaskan } \\
\text { proses suatu } \\
\text { unsur untuk } \\
\text { mencapai } \\
\text { kestabilannya. }\end{array}$} & $\begin{array}{l}\text { 1. } \begin{array}{l}\text { Menuliskan } \\
\text { konfigurasi } \\
\text { elektron }\end{array} \\
\text { ela }\end{array}$ & 1.1 & $94 \%$ & $\begin{array}{l}\text { Sangat } \\
\text { Tinggi }\end{array}$ \\
\hline & $\begin{array}{ll}\text { 2. } & \text { Menentukan } \\
& \text { elektron valensi } \\
\text { suatu unsur }\end{array}$ & 1.2 & $94 \%$ & $\begin{array}{l}\text { Sangat } \\
\text { Tinggi }\end{array}$ \\
\hline & $\begin{array}{l}\text { 3. Menggambarkan } \\
\text { struktur Lewis } \\
\text { senyawa }\end{array}$ & 1.3 & $62 \%$ & Sedang \\
\hline & $\begin{array}{l}\text { Menggambarkan } \\
\text { cara suatu unsur } \\
\text { untuk mencapai } \\
\text { kestabilan }\end{array}$ & 1.4 & $74 \%$ & Tinggi \\
\hline \multirow{2}{*}{$\begin{array}{l}\text { Menggambarkan } \\
\text { susunan elektron } \\
\text { valensi atom gas } \\
\text { mulia (duplet dan } \\
\text { okted) dan } \\
\text { elektron valensi } \\
\text { bukan gas mulia } \\
\text { (struktur Lewis). }\end{array}$} & $\begin{array}{ll}\text { 5. } & \text { Mengelompokan } \\
\text { unsur gas mulia } \\
\text { dan bukan gas } \\
\text { mulia. }\end{array}$ & 2.a & $22 \%$ & Rendah \\
\hline & $\begin{array}{l}\text { 6. } \begin{array}{l}\text { Menjelaskan } \\
\text { aturan duplet dan } \\
\text { aturan oktet }\end{array}\end{array}$ & $2 . b$ & $20 \%$ & Rendah \\
\hline $\begin{array}{l}\text { Menjelaskan } \\
\text { proses } \\
\text { terbentuknya } \\
\text { ikatan ion. }\end{array}$ & $\begin{array}{ll}\text { 7. } & \text { Menjelaskan } \\
\text { proses } \\
\text { terbentuknya } \\
\text { ikatan ion. }\end{array}$ & 3 & $49 \%$ & Sedang \\
\hline $\begin{array}{l}\text { Menjelaskan } \\
\text { proses } \\
\text { terbentuknya } \\
\text { ikatan kovalen. }\end{array}$ & $\begin{array}{ll}\text { 8. } & \text { Menggambarkan } \\
\text { struktur Lewis } \\
\text { dan menentukan } \\
\text { rumus kimia } \\
\text { senyawa ikatan } \\
\text { kovalen tunggal }\end{array}$ & $4 . a$ & $51 \%$ & Sedang \\
\hline
\end{tabular}




\begin{tabular}{|c|c|c|c|c|}
\hline & $\begin{array}{l}\text { 9. } \\
\text { Menggambarkan } \\
\text { struktur Lewis } \\
\text { dan menentukan } \\
\text { rumus kimia } \\
\text { senyawa ikatan } \\
\text { kovalen rangkap } \\
\text { dua. }\end{array}$ & 4.b & $65 \%$ & Sedang \\
\hline & $\begin{array}{l}\text { 10. Menggambarkan } \\
\text { struktur Lewis } \\
\text { dan menentukan } \\
\text { rumus kimia } \\
\text { senyawa ikatan } \\
\text { kovalen rangkap } \\
\text { tiga. }\end{array}$ & 4.c & $40 \%$ & Rendah \\
\hline & $\begin{array}{l}\text { 11. Menjelaskan } \\
\text { proses } \\
\text { terbentuknya } \\
\text { ikatan kovalen } \\
\text { koordinasi. }\end{array}$ & 5 & $29 \%$ & Rendah \\
\hline \multirow{2}{*}{$\begin{array}{l}\text { Menjelaskan } \\
\text { proses } \\
\text { terbentuknya } \\
\text { ikatan logam dan } \\
\text { hubunganya } \\
\text { dengan sifat } \\
\text { senyawa yang } \\
\text { berikatan logam }\end{array}$} & $\begin{array}{l}\text { 12. } \text { Menjelaskan } \\
\text { proses } \\
\text { pembentukan } \\
\text { ikatan logam }\end{array}$ & 6 & $31 \%$ & Rendah \\
\hline & $\begin{array}{l}\text { 13. Menjelaskan sifat } \\
\text { senyawa yang ber } \\
\text { ikatan logam }\end{array}$ & 7 & $45 \%$ & Rendah \\
\hline \multicolumn{3}{|c|}{ Rata-rata penguasaan konsep } & $55 \%$ & Sedang \\
\hline
\end{tabular}

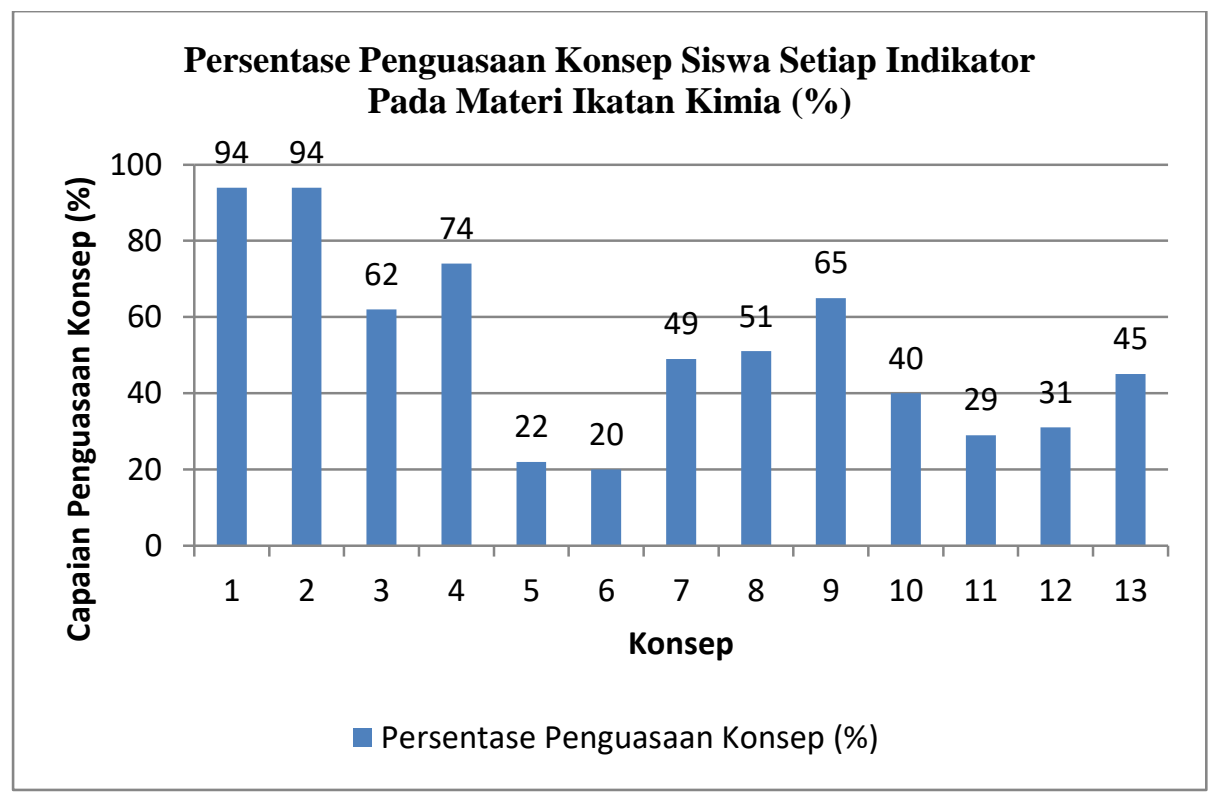

\section{Gambar 1. Grafik Capaian Penguasaan Konsep Siswa Per Indikator Pada Materi Ikatan Kimia.}

Grafik 1 menunjukkan capaian penguasaan konsep siswa, dimana penguasaan konsep siswa pada sub indikator 1 dan 2 berada pada kategori sangat tinggi, pada sub indikator 4 berada pada kategori tinggi, pada sub indikator 3, 7, 8, 9 berada 
pada kategori sedang, dan pada kategori 5, 6, 10, 11, 12, dan 13 berada pada kategori rendah.

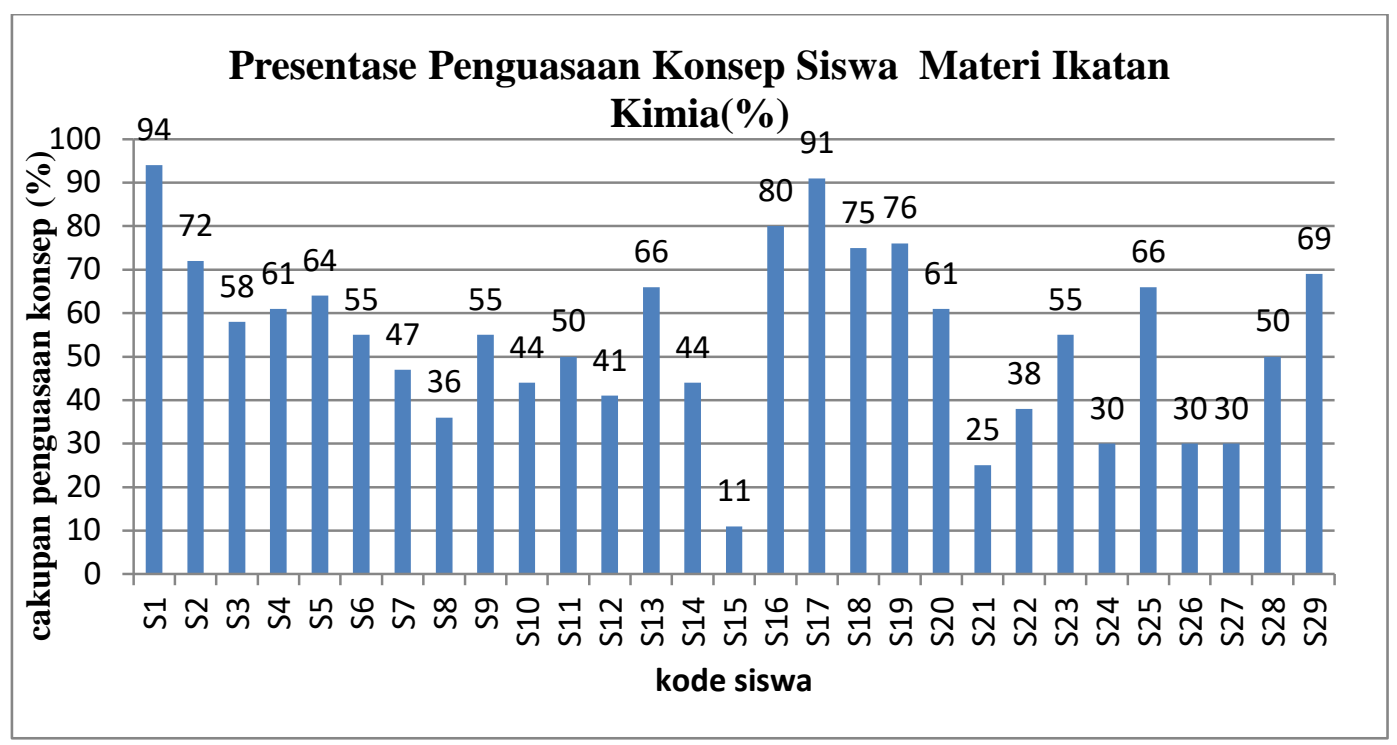

Gambar 2. Grafik persentase penguasaan konsep siswa materi ikatan kimia

Kriteria ketuntasan minimal siswa pada materi ikatan kimia sebesar 79. Hasil penguasaan konsep ikatan kimia masing-masing siswa pada grafik 2 menunjukan terdapat 3 siswa memperoleh nilai tuntas diantas KKM, dan sebanyak 26 siswa memperoleh nilai dibawah KKM. Sebagaimana dipaparkan pada grafik..

\section{Deskripsi Kesesuaian Isi RPP dengan Pencapaian Kompertensi Menurut Kurikulum 2013}

Rencana Pelaksanaan Pembelajaran (RPP) yang diamati dan di analisis adalah RPP yang dibuat oleh guru berdasarkan kurikulum 2013. Untuk menganalisis RPP tersebut digunakan pedoman seperti pada tabel ( 4 ) berikut.

Tabel 4. Kelengkapan Komponen RPP

\begin{tabular}{|c|c|c|c|}
\hline \multirow[t]{2}{*}{ No } & \multirow[t]{2}{*}{ Aspek Yang Diamati } & \multicolumn{2}{|c|}{ RPP } \\
\hline & & Ada & $\begin{array}{c}\text { Tidak } \\
\text { Ada }\end{array}$ \\
\hline & Identitas Sekolah & $\sqrt{ }$ & \\
\hline & A. Satuan Pendidikan & $\sqrt{ }$ & \\
\hline & B. Kelas & $\sqrt{ }$ & \\
\hline 1 & C. Semester & $\sqrt{ }$ & \\
\hline & D. Mata Pelajaran & $\sqrt{ }$ & \\
\hline & E. Materi Pokok & $\sqrt{ }$ & \\
\hline & F. Alokasi Waktu & $\sqrt{ }$ & \\
\hline 2 & Kompetensi Inti & & $\sqrt{ }$ \\
\hline 3 & Kompetensi Dasar & $\sqrt{ }$ & \\
\hline 4 & Indikator & $\sqrt{ }$ & \\
\hline 5 & Tujuan Pembelajaran & $\sqrt{ }$ & \\
\hline 6 & Materi Pembelajaran & $\sqrt{ }$ & \\
\hline 7 & Metode Pembelajaran & $\sqrt{ }$ & \\
\hline
\end{tabular}




\begin{tabular}{|c|c|c|c|}
\hline \multirow[t]{2}{*}{ No } & \multirow[t]{2}{*}{ Aspek Yang Diamati } & \multicolumn{2}{|c|}{ RPP } \\
\hline & & Ada & $\begin{array}{c}\text { Tidak } \\
\text { Ada }\end{array}$ \\
\hline 8 & Media Pembelajaran & $\sqrt{ }$ & \\
\hline 9 & Alat dan Bahan & & $\sqrt{ }$ \\
\hline 10 & Sumber Belajar & $\sqrt{ }$ & \\
\hline \multirow{15}{*}{11} & Rencana Kegiatan Pembelajaraan & $\sqrt{ }$ & \\
\hline & Kegiatan pendahuluan/awal & $\sqrt{ }$ & \\
\hline & 1) Mengkondisikan peserta didik & $\sqrt{ }$ & \\
\hline & $\begin{array}{l}\text { a 2) Mengkaitkan materi sebelumnya dengan } \\
\text { materi yang akan dipelajari }\end{array}$ & $\sqrt{ }$ & \\
\hline & 3) Menyampaikan tujuan pembelajaran & $\sqrt{ }$ & \\
\hline & Kegiatan inti & $\sqrt{ }$ & \\
\hline & 1) Mengamati & $\sqrt{ }$ & \\
\hline & 2) Menanya & $\sqrt{ }$ & \\
\hline & 3) Mengumpulkan data & $\sqrt{ }$ & \\
\hline & 4) Mengasosiasikan & $\sqrt{ }$ & \\
\hline & 5) Mengkomunikasikan & $\sqrt{ }$ & \\
\hline & Kegiatan Penutup & $\sqrt{ }$ & \\
\hline & 1) Meninjau kembali & $\sqrt{ }$ & \\
\hline & 2) Mengevaluasi & $\sqrt{ }$ & \\
\hline & 3) Tindak lanjut & $\sqrt{ }$ & \\
\hline \multirow[t]{4}{*}{12} & Penilaian & $\sqrt{ }$ & \\
\hline & a Jenis/teknik penilaian & $\sqrt{ }$ & \\
\hline & b Bentuk instrumen dan instrumen & $\sqrt{ }$ & \\
\hline & c Pedoman penskoran & & $\sqrt{ }$ \\
\hline
\end{tabular}
Keterangan :

$(\sqrt{ })=$ Terpenuhi

$(-)=$ Tidak terpenuhi

Berdasarkan data analisis komponen isi RPP guru, bahwa hasil analisis RPP tersebut secara umum isinya telah sesuai eperti pada aspek yang diamati. Adapun pada penelitian ini, secara spesifik memperhatikan pada aspek keterkaitan KI, KD, indikator pencapaian kompetensi, tujuan pembelajaran, materi pembelajaran, serta model pembelajaran yang digunakan. Berikut diuraikan keterkaitan antara komponen-komponen tersebut..

Berdasarkan peta konsep tersebut dirumuskanlah indikator dan sub indikator yang sesuai sebagai berikut.

Tabel 7. Kesesuaian Materi Pembelajaran Terhadap Indikator Tes, dan Sub Indikator Tes

\begin{tabular}{lll}
\hline Materi Pembelajaran & \multicolumn{1}{c}{ Indikator Tes } & \multicolumn{1}{c}{ Sub Indikator Tes } \\
\hline - Konfigurasi & & Menuliskan konfigurasi \\
elektron & Menjelaskan proses suatu & elektron unsur \\
\cline { 2 - 2 } - Elektron valensi & unsur untuk mencapai & Menentukan elektron \\
- Kestabilan unsur & kestabilannya. & valensi suatu unsur \\
- Ikatan ion & & Menggambarkan struktur \\
\hline
\end{tabular}


- Penyetaraan reaksi

- Ikatan kovalen rangkap satu, rangkap dua,dan rangkap tiga

- Ikatan kovalen koordinasi

- Ikatan logam

- Sifat senyawa yang berikatan logam

\section{Menggambarkan cara} suatu unsur untuk mencapai kestabilan

\section{Menggambarkan susunan} Mengelompokan unsur elektron valensi atom gas mulia (duplet dan okted) dan elektron valensi bukan gas mulia (struktur Lewis). gas mulia dan bukan gas mulia.

Menjelaskan aturan duplet dan aturan octet
Menjelaskan proses terbentuknya ikatan ion.

\begin{tabular}{ll}
\hline Menjelaskan proses & Menggambarkan struktur \\
terbentuknya ikatan kovalen. & $\begin{array}{l}\text { Lewis dan menentukan } \\
\text { rumus kimia senyawa } \\
\text { ikatan kovalen tunggal }\end{array}$ \\
\cline { 2 - 2 } & Menggambarkan struktur \\
& Lewis dan menentukan \\
rumus kimia senyawa \\
ikatan kovalen rangkap \\
dua.
\end{tabular}

\section{Deskripsi Penguasaan Konsep Siswa Pada Topik Ikatan Kimia}

Tujuan utama dari penelitian ini adalah untuk mendeskripsikan Penguasaan konsep ikatan kimia pada siswa. Hasil penelitian menunjukkan bahwa rata-rata penguasaan konsep siswa adalah sebesar 55\%.

Tabel 8 menunjukkan distribusi tingkat penguasaan konsep siswa pada materi ikatan kimia dimana jumlah siswa didominasi pada kategori sedang dan rendah yaitu sama-sama sebanyak 10 siswa, sedangkan pada kategori sangat tinggi hanya dua siswa. Kemudian sebanyak tujuh siswa berada pada kategori tinggi. 
Tabel 8. Distribusi Tingkat Penguasaan Konsep Siswa

\begin{tabular}{|c|c|c|c|}
\hline Kategori & Kode Siswa & $\begin{array}{l}\text { Jumlah } \\
\text { Siswa }\end{array}$ & $\begin{array}{l}\text { Persentasi Jumlah } \\
\text { Siswa }(\%)\end{array}$ \\
\hline Sangat & $\mathrm{S} 1, \mathrm{~S} 17$ & 2 & 6,9 \\
\hline Tinggi & & & \\
\hline Tinggi & $\begin{array}{l}\text { S2, S13, S16, S18, S19, S25, } \\
\text { S29 }\end{array}$ & 7 & 24,1 \\
\hline Sedang & $\begin{array}{l}\text { S3, S4, S5, S6, S7, S9, S11, } \\
\text { S0, S3, S8 }\end{array}$ & 10 & 34,5 \\
\hline Rendah & $\begin{array}{l}\text { S8, S10, S12, S14, S15, S21, } \\
\text { S22, S24, S26, S7 }\end{array}$ & 10 & 34,5 \\
\hline
\end{tabular}

\section{Menjelaskan proses suatu unsur untuk mencapai kestabilannya.}

\section{Menuliskan konfigurasi elektron unsur}

Kemampuan siswa dalam menuliskan konfigurasi elektron suatu unsur ditunjukan pada lampiran 7 berada pada kategori sangat tinggi yaitu 94\%. Hal tersebut menunjukan bahwa sebagian besar siswa sudah memiliki penguasaan konsep yang baik pada topik ini. Skor maksimum untuk soal nomor 1.1 adalah 3 . Pemberian skor berdasarkan kriteria yang telah dibuat sesuai dengan langkahlangkah penyelesaian soal. Kriteria penilaian tersebut menggambarkan konsep yang diperoleh siswa, deskripsi penguasaan konsep siswa untuk menuliskan konfigurasi elektron unsur dimuat dalam tabel dibawah ini.

Tabel 9. Deskripsi Penguasaan konsep dan Skor Jawaban Siswa Pada Butir Soal 1.1

\begin{tabular}{lc}
\hline \multicolumn{1}{c}{ Deskripsi Penguasaan konsep } & Skor \\
\hline Tidak menjawab, mengulang pertanyaan, jawaban tidak jelas dan tidak & 0 \\
relevan & \\
\hline Dapat menuliskan konfigurasielektron unsur Na & 1 \\
Dapat menuliskan konfigurasielektron unsur F & 1 \\
Dapat menuliskan konfigurasielektron unsur Cl & 1 \\
\hline
\end{tabular}

\section{Menentukan elektron valensi suatu unsur}

Kemampuan siswa dalam menentukan elektron valensi pada lampiran 7 berada pada kategori sangat tinggi yaitu 94\%. Hal tersebut menunjukan bahwa sebagian besar siswa sudah memiliki penguasaan konsep yang sangat baik pada topik ini. Skor maksimum untuk soal nomor 1.2 adalah 3. Pemberian skor berdasarkan kriteria yang telah dibuat sesuai dengan langkah-langkah penyelesaian soal. Kriteria penilaian tersebut menggambarkan konsep yang diperoleh siswa, deskripsi penguasaan konsep siswa untuk menjelaskan kemampuan siswa menentukan elektron valensi suatu unsur senyawa tersebut dapat dilihat pada tabel dibawah ini

Tabel 10. Deskripsi Penguasaan konsep dan Skor Jawaban Siswa Pada Butir Soal 1.2

\begin{tabular}{lc}
\hline \multicolumn{1}{c}{ Deskripsi Penguasaan konsep } & Skor \\
\hline $\begin{array}{l}\text { Tidak menjawab, mengulang pertanyaan, jawaban tidak jelas dan tidak } \\
\text { relevan }\end{array}$ & 0 \\
\hline
\end{tabular}


Dapat menentukan elektron valensi unsur $\mathrm{Na}$ 1

Dapat menentukan elektron valensi unsur $\mathrm{F}$

Kemampuan siswa dalam menuliskan rumus empiris suatu senyawa ditunjukan pada tabel 10 sebesar 93,33\% berada pada kategori sangat tinggi. Berikut disajikan tabel 16 tentang perolehan jumlah skor siswa yang benar setiap kategori pada butir soal 2 berdasarkan pola jawaban siswa yaitu menuliskan rumus empiris.

\section{Tabel 16. Distribusi Capaian Pada Butir Soal 2}

\begin{tabular}{cccccc}
\hline \multirow{2}{*}{ Kategori Penguasaan } & \multirow{2}{*}{ Jumlah Siswa } & \multicolumn{4}{c}{ Jumlah Skor } \\
\cline { 3 - 6 } & & 0 & 1 & 2 & 3 \\
\hline Sangat Tinggi & 9 & - & - & - & 9 \\
Tinggi & 12 & - & - & - & 12 \\
Sedang & 9 & 2 & 2 & 5 & - \\
Jumlah & $\mathbf{3 0}$ & $\mathbf{2}$ & $\mathbf{2}$ & $\mathbf{5}$ & $\mathbf{2 1}$ \\
Persentase $(\%)$ & $\mathbf{1 0 0}$ & $\mathbf{6 . 6 6}$ & $\mathbf{6 . 6 6}$ & $\mathbf{1 6 . 6 6}$ & $\mathbf{7 0}$ \\
\hline
\end{tabular}

Tabel 16 memaparkan bahwa sebesar $6.66 \%$ siswa memperoleh skor 0 artinya siswa belum mampu menuliskan rumus empiris suatu senyawa dengan benar, sebesar $6.66 \%$ siswa memperoleh skor 1 artinya siswa mampu menuliskn rumus empiris 1 senyawa dengan benar, sebesar $16.66 \%$ siswa memperoleh skor 2 artinya siswa mampu menuliskan rumus empiris 2 senyawa dengan benar, dan sebesar $70 \%$ siswa mampu menuliskan rumus empris 3 senyawa dengan benar.

\section{Menuliskan Nama Senyawa Anorganik dan Senyawa Organik Menggambarkan Struktur Lewis Senyawa}

Kemampuan siswa dalam menggambarkan struktur Lewis senyawa ditunjukan pada lampiran 7 berada pada kategori cukup yaitu 62\%. hal tersebut menunjukan bahwa sebagian siswa belum memiliki penguasaan konsep yang baik pada topik ini. Skor maksimum untuk soal nomor 1.3 adalah 3. Pemberian skor berdasarkan kriteria yang telah dibuat sesuai dengan langkah-langkah penyelesaian soal. Kriteria penilaian tersebut menggambarkan konsep yang diperoleh siswa, deskripsi penguasaan konsep siswa untuk Menggambarkan struktur lewis senyawa dapat dilihat pada tabel 11.

Tabel 11. Deskripsi Penguasaan konsep dan Skor Jawaban Siswa Pada Butir Soal 1.3

\begin{tabular}{lc}
\multicolumn{1}{c}{ Deskripsi Pnguasaan Konsep } & Skor \\
\hline Tidak menjawab, mengulang pertanyaan, jawaban tidak jelas dan tidak & 0 \\
relevan & 1 \\
Dapat menggambarkan struktur Lewis unsur Na & 1 \\
Dapat menggambarkan struktur Lewis unsur F & 1 \\
Dapat menggambarkan struktur Lewis unsur Cl & 1 \\
Dapat menggambarkan struktur Lewis $\mathrm{Cl}_{2}$ dari senyawa yang terbentuk & 1 \\
\hline
\end{tabular}




\section{Menggambarkan cara suatu unsur untuk mencapai kestabilan}

Kemampuan siswa dalam menggambarkan cara suatu unsur untuk mencapai kestabilan tersebut ditunjukan pada lampiran 7 berada pada kategori tinggi yaitu $74 \%$. Hal tersebut menunjukan bahwa sebagian besar siswa memiliki penguasaan konsep yang tinggi pada topik ini. Skor maksimum untuk soal nomor 1.4 adalah 3. Pemberian skor berdasarkan kriteria yang telah dibuat sesuai dengan langkah-langkah penyelesaian soal. Kriteria penilaian tersebut menggambarkan konsep yang diperoleh siswa, deskripsi pemahaman konsep siswa untuk menggambarkan cara suatu unsur untuk mencapai kestabilan tersebut dapat dilihat pada tabel 12.

Tabel 12. Deskripsi penguasaan konsep dan skor Jawaban siswa pada butir soal 1.4

\begin{tabular}{lc}
\hline \multicolumn{1}{c}{ Deskripsi Penguasaan Konsep } & Skor \\
\hline Tidak menjawab, mengulang pertanyaan, jawaban tidak jelas dan tidak & 0 \\
relevan & \\
Dapat menggambarkan cara unsur Na untuk mencapai kestabilan & 1 \\
Dapat menggambarkan cara unsur F untuk mencapai kestabilan & 1 \\
Dapat menggambarkan cara unsur Cl untuk mencapai kestabilan & 1 \\
\hline
\end{tabular}

\section{Menggambarkan susunan elektron valensi atom gas mulia (duplet dan okted) dan elektron valensi bukan gas mulia (struktur Lewis) Mengelompokan unsur gas mulia dan bukan gas mulia.}

Kemampuan siswa dalam mengelompokan unsur gas mulia dan bukan gas mulia ditunjukan pada lampiran 7 berada pada kategori rendah yaitu $22 \%$. Hal tersebut menunjukan bahwa sebagian besar siswa belum memiliki penguasaan konsep yang baik pada topik ini. Skor maksimum untuk soal nomor 2.a adalah 2. Pemberian skor berdasarkan kriteria yang telah dibuat sesuai dengan langkahlangkah penyelesaian soal. Kriteria penilaian tersebut menggambarkan konsep yang diperoleh siswa, deskripsi penguasaan konsep siswa untuk menjelaskan kemampuan siswa dalam mengelompokan unsur gas mulia dan bukan gas mulia.dapat dilihat pada tabel 13.

Tabel 13. Deskripsi Penguasaan konsep dan Skor Jawaban Siswa Pada Butir Soal 2.a

\begin{tabular}{lc}
\hline \multicolumn{1}{c}{ Deskripsi penguasaan konsep } & Skor \\
\hline Tidak menjawab, mengulang pertanyaan, jawaban tidak jelas dan tidak & 0 \\
relevan & \\
Dapat Menuliskan konfigurasi elektron & 1 \\
Dapat mengelompokan unsur kedalam gas mulia dan bukan gas mulia & 1 \\
\hline
\end{tabular}

\section{Menjelaskan aturan duplet dan aturan oktet}

Kemampuan siswa dalam menjelaskan aturan duplet dan aturan oktet ditunjukan pada lampiran 7 berada pada kategori rendah yaitu 20\%. Hal tersebut menunjukan bahwa sebagian besar siswa memiliki penguasaan konsep yang rendah pada topik ini. Skor maksimum untuk soal nomor 2.b adalah 2. Pemberian skor berdasarkan kriteria yang telah dibuat sesuai dengan langkah-langkah penyelesaian soal. Kriteria penilaian tersebut menggambarkan konsep yang 
diperoleh siswa, deskripsi penguasaan konsep siswa untuk menjelaskan kemampuan siswa dalam menjelaskan aturan duplet dan aturan oktet dapat dilihat pada table 14 .

Tabel 14. Deskripsi Penguasaan konsep dan Skor Jawaban Siswa Pada Butir Soal 2.b

\begin{tabular}{lc}
\hline \multicolumn{1}{c}{ Deskripsi Penguasaan Konsep } & Skor \\
\hline $\begin{array}{l}\text { Tidak menjawab, mengulang pertanyaan, jawaban tidak jelas dan tidak } \\
\text { relevan }\end{array}$ & 0 \\
$\begin{array}{l}\text { Dapat menuliskan cara suatu unsur untuk mencapai kestabilan } \\
\text { Menjelaskan perbedaan unsur dalam mencapai kestabilan berdasarkan } \\
\text { aturan oktet dan duplet }\end{array}$ & 1 \\
\hline
\end{tabular}

\section{Menjelaskan proses terbentuknya ikatan ion}

Kemampuan siswa dalam menjelaskan proses terbentuknya ikatan ion ditunjukan pada lampiran 7 berada pada kategori kurang yaitu 49\%. Hal tersebut menunjukan bahwa sebagian besar siswa kurang menguasai konsep pada topik ini. Skor maksimum untuk soal nomor 3 adalah 4. Pemberian skor berdasarkan kriteria yang telah dibuat sesuai dengan langkah-langkah penyelesaian soal. Kriteria penilaian tersebut menggambarkan konsep yang diperoleh siswa, deskripsi penguasaan konsep siswa untuk menjelaskan kemampuan siswa dalam menjelaskan proses terbentuknya ikatan ion dapat dilihat pada table 15 .

Tabel 15. Deskripsi Penguasaan Konsep dan Skor Jawaban Siswa Pada Butir Soal 3

\begin{tabular}{lc}
\hline \multicolumn{1}{c}{ Deskripsi Penguasaan Konsep } & Skor \\
\hline $\begin{array}{l}\text { Tidak menjawab, mengulang pertanyaan, jawaban tidak jelas dan tidak } \\
\text { relevan }\end{array}$ & 0 \\
$\begin{array}{l}\text { Dapat menuliskan konfigurasi elektron kedua unsur } \\
\text { Dapat menentukan jumlah elektron yang dilepas atau diterima oleh unsur }\end{array}$ & 1 \\
$\begin{array}{l}\text { Dapat menyamakan jumlah elektron sehingga diketahui rumus kimia } \\
\text { senyawanya }\end{array}$ & 1 \\
$\begin{array}{l}\text { Dapat menggambarkan Interaksi antar ion positif dan ion negatif } \\
\text { berdasarkan lambang Lewis }\end{array}$ & 1 \\
\hline
\end{tabular}

Menjelaskan proses terbentuknya ikatan kovalen

Menggambarkan struktur Lewis dan menentukan rumus kimia senyawa ikatan kovalen tunggal

Kemampuan siswa dalam menggambarkan struktur Lewis dan menentukan rumus kimia senyawa ikatan kovalen tunggal dapat dilihat pada lampiran 7 berada pada kategori cukup yaitu 51\%. Hal tersebut menunjukan bahwa sebagian siswa sudah memiliki penguasan konsep yang baik pada topik ini. Skor maksimum untuk soal nomor 4.a adalah 3. Pemberian skor berdasarkan kriteria yang telah dibuat sesuai dengan langkah-langkah penyelesaian soal. Kriteria penilaian tersebut menggambarkan konsep yang diperoleh siswa, deskripsi penguasaan konsep siswa untuk menggambarkan struktur Lewis dan menentukan rumus kimia senyawa ikatan kovalen tunggal dapat dilihat pada tabel 16. 
Tabel 16. Deskripsi Penguasaan konsep dan Skor Jawaban Siswa Pada Butir Soal 4.a

\begin{tabular}{lc}
\hline \multicolumn{1}{c}{ Deskripsi Penguasaan Konsep } & Skor \\
\hline Tidak menjawab, mengulang pertanyaan, jawaban tidak jelas dan tidak & 0 \\
relevan & \\
Dapat menuliskan konfigurasi elektron & 1 \\
Dapat menggambarkan struktur Lewis ikatan & 1 \\
Dapat Menuliskan rumus kimia yang terbentuk & 1 \\
\hline
\end{tabular}

Menggambarkan struktur Lewis dan menentukan rumus kimia senyawa ikatan kovalen rangkap dua

Kemampuan siswa dalam menggambarkan struktur Lewis dan menentukan rumus kimia senyawa ikatan kovalen rangkap dua ditunjukan pada lampiran 7 berada pada kategori sedang yaitu $65 \%$. Hal tersebut menunjukan bahwa sebagian siswa belum memiliki penguasaan konsep yang baik pada topik ini. Skor maksimum untuk soal nomor 4.b adalah 3. Pemberian skor berdasarkan kriteria yang telah dibuat sesuai dengan langkah-langkah penyelesaian soal. Kriteria penilaian tersebut menggambarkan konsep yang diperoleh siswa, deskripsi penguasaan konsep siswa untuk menjelaskan kemampuan siswa menggambarkan struktur Lewis dan menentukan rumus kimia senyawa ikatan kovalen rangkap dua dapat dilihat pada tabel 17.

Tabel 17. Deskripsi penguasaan konsep dan skor jawaban siswa pada butir soal 4.b

\begin{tabular}{lc}
\hline \multicolumn{1}{c}{ Deskripsi Penguasaan Konsep } & Skor \\
\hline Tidak menjawab, mengulang pertanyaan, jawaban tidak jelas dan tidak & 0 \\
relevan & \\
Dapat menuliskan konfigurasi elektron & 1 \\
Dapat menggambarkan struktur Lewis ikatan & 1 \\
Dapat Menuliskan rumus kimia yang terbentuk & 1 \\
\hline
\end{tabular}

\section{Menggambarkan struktur Lewis dan menentukan rumus kimia senyawa ikatan kovalen rangkap tiga}

Kemampuan siswa dalam menggambarkan struktur Lewis dan menentukan rumus kimia senyawa ikatan kovalen rangkap tiga ditunjukan pada lampiran 7 berada pada kategori kurang yaitu 40\%. Hal tersebut menunjukan bahwa seluruh siswa belum memiliki penguasaan konsep yang baik pada topik ini. Skor maksimum untuk soal nomor 4.c adalah 3. Pemberian skor berdasarkan kriteria yang telah dibuat sesuai dengan langkah-langkah penyelesaian soal. Kriteria penilaian tersebut menggambarkan konsep yang diperoleh siswa, deskripsi penguasaan konsep siswa untuk menjelaskan kemampuan siswa menggambarkan struktur Lewis dan menentukan rumus kimia senyawa ikatan kovalen rangkap tiga dapat dilihat pada tabel 18 .

Tabel 18. Deskripsi Penguasaan konsep dan Skor Jawaban Siswa Pada Butir Soal 4.c

\begin{tabular}{cc}
\hline Deskripsi Penguasaan Konsep & Skor \\
\hline Tidak menjawab, mengulang pertanyaan, jawaban tidak jelas dan tidak & 0
\end{tabular}




\section{relevan}

Dapat menuliskan konfigurasi elektron

Dapat menggambarkan struktur lewis ikatan

\section{Menjelaskan proses terbentuknya ikatan kovalen koordinasi}

Kemampuan siswa dalam menjelaskan proses terbentuknya ikatan kovalen koordinasi ditunjukan pada lampiran 7 berada pada kategori kurang yaitu $29 \%$. Hal tersebut menunjukan bahwa seluruh siswa belum memiliki penguasaan konsep yang baik pada topik ini. Skor maksimum untuk soal nomor 5 adalah 4. Pemberian skor berdasarkan kriteria yang telah dibuat sesuai dengan langkahlangkah penyelesaian soal. Kriteria penilaian tersebut menggambarkan konsep yang diperoleh siswa, deskripsi penguasaan konsep siswa untuk menjelaskan kemampuan siswa menjelaskan proses terbentuknya ikatan kovalen koordinasi dapat dilihat pada tabel 19 .

\section{Tabel 19. Deskripsi Penguasaan Konsep dan Skor Jawaban Siswa Pada Butir} Soal 5

\begin{tabular}{lc}
\hline \multicolumn{1}{c}{ Deskripsi Penguasaan Konsep } & Skor \\
\hline Tidak menjawab, mengulang pertanyaan, jawaban tidak jelas dan tidak & 0 \\
relevan & 1 \\
Dapat menuliskan konfigurasi elektron & 1 \\
Dapat menggambarkan struktur Lewis masing-masing Unsur & 1 \\
Dapat menggambarkan struktur Lewis senyawa & 1 \\
Dapat menunjukan ikatan kovalen koordinasi dengan benar & \\
\hline
\end{tabular}

\section{Menjelaskan proses terbentuknya ikatan logam dan hubunganya dengan sifat senyawa yang berikatan logam Menjelaskan proses pembentukan ikatan logam}

Kemampuan siswa dalam menjelaskan proses pembentukan ikatan logam dapat dilihat pada lampiran 7 berada pada kategori kurang yaitu $31 \%$. Hal tersebut menunjukan bahwa siswa belum memiliki penguasaan konsep yang baik pada topik ini. Skor maksimum untuk soal nomor 6 adalah 1. Pemberian skor berdasarkan kriteria yang telah dibuat sesuai dengan langkah-langkah penyelesaian soal. Kriteria penilaian tersebut menggambarkan konsep yang diperoleh siswa, deskripsi penguasaan konsep siswa untuk menjelaskan proses pembentukan ikatan logam dapat dilihat pada tabel 20.

Tabel 20. Deskripsi Penguasaan Konsep dan Skor Jawaban Siswa Pada Butir Soal 6

\section{Deskripsi penguasaan konsep} Skor

Tidak menjawab, mengulang pertanyaan, jawaban tidak jelas dan tidak relevan

Dapat menjelaskan proses pembentukan ikatan logam dengan benar

\section{Menjelaskan sifat senyawa yang berikatan logam}

Kemampuan siswa dalam menjelaskan sifat senyawa yang berikatan logam dapat dilihat pada lampiran 7 berada pada kategori kurang yaitu 45\%. Hal 
tersebut menunjukan bahwa siswa belum memiliki penguasaan konsep yang baik pada topik ini. Skor maksimum untuk soal nomor 7 adalah 1. Pemberian skor berdasarkan kriteria yang telah dibuat sesuai dengan langkah-langkah penyelesaian soal. Kriteria penilaian tersebut menggambarkan konsep yang diperoleh siswa, deskripsi penguasaan konsep siswa untuk menjelaskan sifat senyawa yang berikatan logam dapat dilihat pada tabel 21 .

\section{Tabel 21. Deskripsi Penguasaan Konsep dan Skor Jawaban Siswa Pada Butir} Soal 7

\begin{tabular}{lc}
\hline \multicolumn{1}{c}{ Deskripsi Penguasaan Konsep } & Skor \\
\hline Tidak menjawab, mengulang pertanyaan, jawaban tidak jelas dan tidak & 0 \\
relevan & \\
Dapat menjelaskan sifat senyawa yang berikatan logam dengan benar & 1 \\
\hline
\end{tabular}

\section{SIMPULAN}

Hasil penelitian dan analisis data yang dilakukan disimpulkan bahwa ratarata penguasan konsep ikatan kimia pada siswa kelas X SMA Negeri 4 Palangka Raya yaitu sebesar 55\% berada pada kategori sedang. Penguasaan konsep siswa disimpulkan sebagai berikut:

1. Penguasaan konsep menuliskan konfigurasi elektron dan menentukan elektron valensi unsur dengan penguasaan konsep sebesar 94\% berada pada kategori sangat tinggi.

2. Penguasaan konsep menggambarkan struktur Lewis dengan penguasaan konsep sebesar $62 \%$ berada pada kategori sedang.

3. Penguasaan konsep menggambarkan cara suatu unsur untuk mencapai kestabilan dengan penguasaan konsep sebesar $74 \%$ berada pada kategori tinggi

4. Penguasaan konsep mengelompokan unsur gas mulia dan bukan gas mulia dengan penguasaan konsep sebesar $22 \%$ berada pada kategori rendah.

5. Penguasaan konsep menjelaskan aturan duplet dan aturan oktet dengan penguasaan konsep sebesar $20 \%$ berada pada kategori rendah.

6. Penguasaan konsep menjelaskan proses terbentuknya ikatan ion dengan penguasaan konsep sebesar $49 \%$ berada pada kategori sedang.

7. Penguasaan konsep menggambarkan struktur Lewis dan menentukan rumus kimia senyawa ikatan kovalen tunggal dengan penguasaan konsep sebesar $51 \%$ berada pada kategori sedang.

8. Penguasaan konsep menggambarkan struktur Lewis dan menentukan rumus kimia senyawa ikatan kovalen rangkap dua dengan penguasaan konsep sebesar $65 \%$ berada pada kategori sedang.

9. Penguasaan konsep menggambarkan struktur Lewis dan menentukan rumus kimia senyawa ikatan kovalen rangkap tiga dengan penguasaan konsep sebesar $40 \%$ berada pada kategori rendah.

10. Penguasaan konsep menjelaskan proses terbentuknya ikatan kovalen koordinasi dengan penguasaan konsep sebesar $29 \%$ berada pada kategori rendah. 
11. Penguasaan konsep menjelaskan proses pembentukan ikatan logam dan menjelaskan sifat senyawa yang berikatan logam dengan penguasaan konsep sebesar $31 \%$ dan $45 \%$ berada pada kategori rendah.

\section{DAFTAR PUSTAKA}

Asi, N.B. 2018. Dimensi Pengetahuan Dan Tingkat Berpikir Pada Pembelajaran Kimia. Jurnal Ilmiah Kanderang Tingang. 9, 2 (Des. 2018), 103-113.

Asi, Y., Abudarin and Asi, N.B. 2019. Pengaruh Pemberian Latihan Soal Terstruktur Setelah Pembelajaran Langsung Terhadap Pemahaman Konsep Ikatan Ion Pada Siswa Kelas X IPA SMA Negeri 4 Palangka Raya Tahun Ajaran 2018/2019. Jurnal Ilmiah Kanderang Tingang. 10, 1 (Jun. 2019), 104-111.

Helfiana, M. 2016. Penguasaan Konsep Pada Materi Tata Nama Senyawa Melalui Pembelajaran Berbasis Inkuiri Siswa Kelas X Sman I Labuhanhaji. Darussalam-Banda Aceh: Universitas Islam Negeri ArRaniry.

Otania, M., Abudarin and Asi, N.B. 2019. Pengaruh Pemberian Latihan Soal Terstruktur Setelah Pembelajaran Langsung Terhadap Pemahaman Konsep Ikatan Kovalen Pada Siswa Kelas X IPA SMA Negeri 4 Palangka Raya Tahun Ajaran 2018/2019. Jurnal Ilmiah Kanderang Tingang. 10, 1 (Jun. 2019), 95-103.

Ribka. 2014. Kesulitan Memahami Konsep Ikatan Kimia Kelas XI IPA SMA Di Buntok Tahun Ajaran 2014/2015. Skripsi Tidak Diterbitkan: Universitas Palangka Raya.

Sulistyowati, Tri \& Poedjiastoeti, Sri. 2013. Kelayakan Multimedia Interaktif Berbasis Intertekstual Pada Materi Reaksi Kimia Untuk Kelas X SMA. Unesa Journal of Chemical Education ISSN : 2252-9454 Vol.2 No.3 pp.57-63

Yulieet. 2015. Pemahaman Konsep Ikatan Ion Pasca Pembelajaran dengan metode diskusi Betrbantuan Media Handout Bergambar Pada siswa Kelas X Lintas Minat SMAN 4 Palangka raya Tahun 2015/2016. Skripsi Tidak Diterbitkan: Universitas Palangka Raya. 